\title{
PRE-PRESSED AND BURNT SANDY CLAY TILES USED TO COVER EXPOSED CONCRETE ROOFS AS A SUSTAINABLE ALTERNATIVE
}

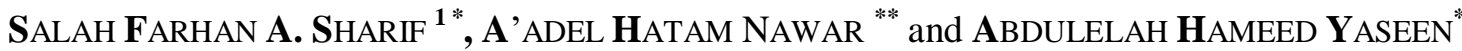 \\ "College of Engineering, Al-Kitab University, A'alton Copry-Iraq \\ ** Dept. of Civil Engineering, College of Engineering, University of Al-Anbar, Anbar-Iraq
}

(Accepted for Publication: December 8, 2020)

\begin{abstract}
Traditional method of concrete ceiling used in Iraq is composed of covering the steel reinforced concrete roofs with a thin layer of asphalt covered by $7-15 \mathrm{~cm}$ river sand, as a minimum, and then covered with concrete slabs $80 \times 80 \times 5 \mathrm{~cm}$ which are both, heavy materials and highly conductive causing severe problems of cost, cooling and heating tasks. In this research work a sustainable construction materials were studied to replace those conductive and unsustainable materials. A layer of putty clay with straw is used as a mortar on the asphalt coated concrete roof surface and then covered with tiles made of burned sandy clay. Pre-pressed Burnt Sandy Clay Tiles (PBSCT) were developed, produced and tested by the researchers. Used raw materials for slab manufacturing were withdrawn from Al-Anbar western desert. Chemical and physical analysis reviled that the best selected samples were from A'amj \& Al-Husayniat quarries. Test results showed that higher silicon content, lower magnesium, potassium and sodium compounds leads to better slabs specifications. Higher compressive strength was obtained with higher burning temperatures as results showed 3.7 (M Pa) was the maximum reading for A'amj \& Al-Husayniat clays with burning temperature of $1320{ }^{\circ} \mathrm{C}$. Breakdown test shows that the max result was $1.43(\mathrm{M} \mathrm{Pa})$ at the same temperature.
\end{abstract}

KEYWORDS: Sustainable Construction Materials, Concrete Roofs Tilling, and Burnt Sandy Clay Tiles.

\section{INTRODUCTION}

$\mathbf{G}$ rowing concerns about global warming and a decrease in natural resources have led to numerous research papers on developing innovative ways to produce green and sustainable building materials (World Green Building Council). Using environmentally friendly alternative materials to replace pre-cast concrete building blocks is a new way to meet emerging needs. The main challenge in this research is to use alternative materials than the materials used to finish or cover the concrete surfaces, which are widely used in Iraq.

Sustainable construction is sometimes called sustainable design or green building (Green Building and Sustainable Design, 2018). Green building methods allow saving energy and thus becoming more environmentally friendly by reducing $\mathrm{CO}_{2}$ emissions. Therefore, the main purposes of green buildings are to use energy efficiently, to ensure that the construction is healthy for the residents. In green buildings, local materials are usually used in addition to this technology helps reduce transportation costs for these materials (Rahul V. Ralegaonkar, 2016).

The traditional method of roofs tiling in Iraq is to cover the steel-reinforced concrete ceiling with heavy and highly thermal conductive materials (figures 1 and 2). This causes the need for increased foundations costs and high energy consumption for cooling and heating in summer and winter, especially in the opposite extremes of the Iraqi summer and winter. Calculation, in the following sections, shows that, by using traditional materials, higher rate of heat transfer through traditional roofs tiling were achieved.

dr.salahfarhan@gmail.com, adilhatem311@uoanbar.edu.iq, abdulelah_6@yahoo.com $278{ }^{1}$ Corresponding author: College of Engineering, Al-Kitab University, A'alton Copry, Iraq 


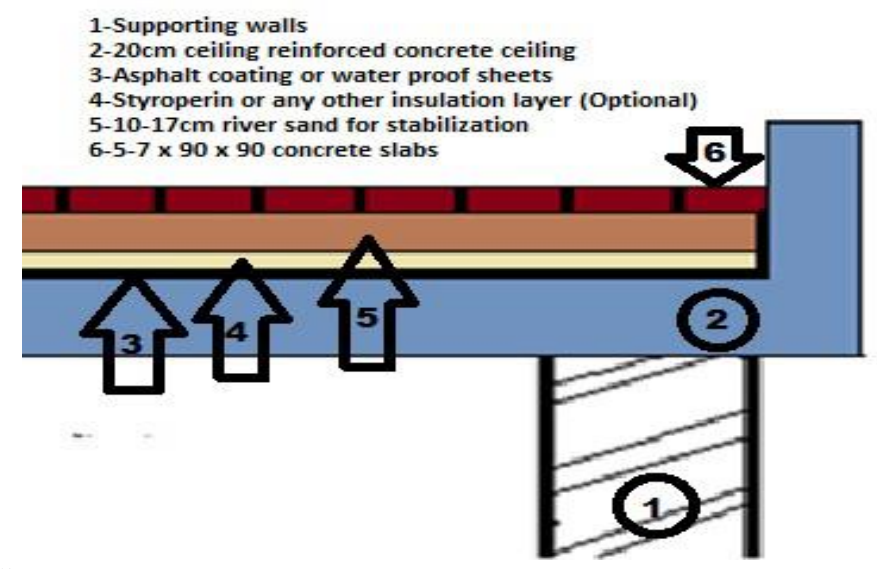

Fig. (1): Traditional method of concrete roofs tiling in Iraq (Adel H. Nawar, 2011)
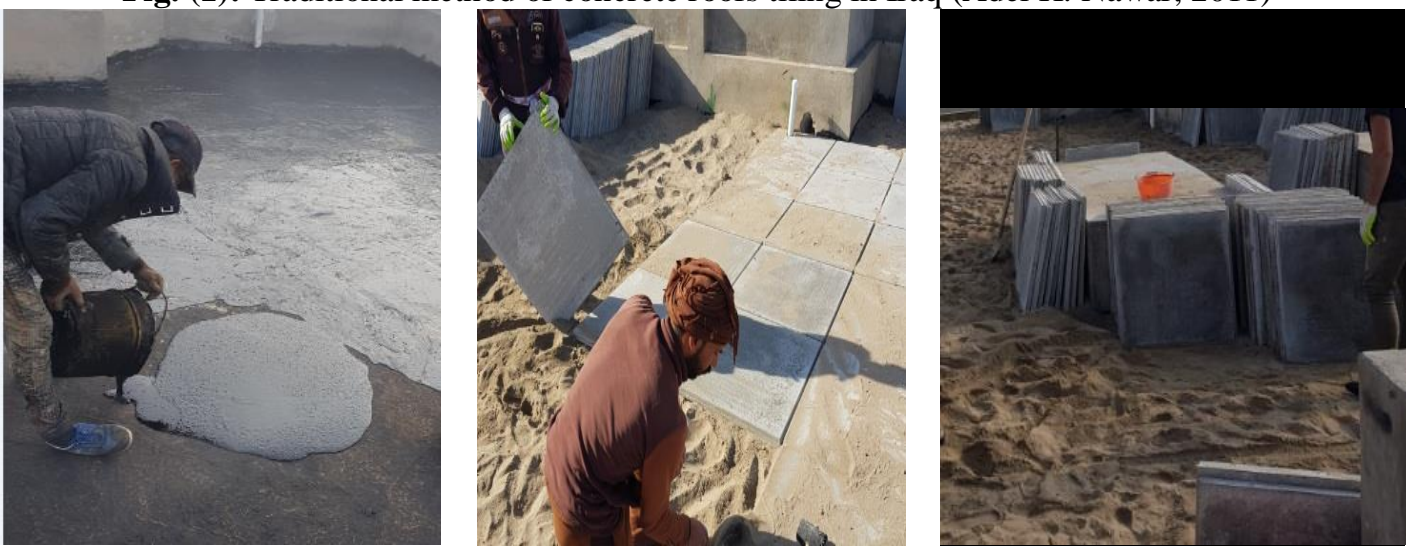

Fig. (2): Asphalt Coating and Traditional Concrete Slabs Tiling (Al-Anbar / Iraq)

Burnt clay bricks have been used since ancient times and are made in various ways in most countries of the world. The main advantages of clay bricks are that they are light, heat and sound insulating and can be shaped in different shapes and sizes. The traditional clay bricks in Iraq are, simply, made from pure clay dough either by molding or by extrusion method. After drying the produced shapes, they are burnt with closed furnaces with temperatures ranging between $750-900{ }^{\circ} \mathrm{C}$. Among the Iraqi clay brick types is the so-called (Farshi brick), which carries the same specifications as building bricks, except the dimensions, usually $(25 * 25 *$ 5) centimeters. This type of bricks used in the past time as tiling materials for interior surfaces and exposed roofs and many other uses such as wall building and decorations as shown in Figure 3 (A'aed Jassam, "Bricks Industry in Iraq", January 2014). This type of tiling bricks, which has the same characteristics of normal Iraqi clay bricks, is no more in use for tiling because of many inconvenient specifications such as low durability, high erosion, high water absorption, sulfur content and low breakdown strength (Alaa A. Shakir, Ali Ahmed Mohammed, 2013).
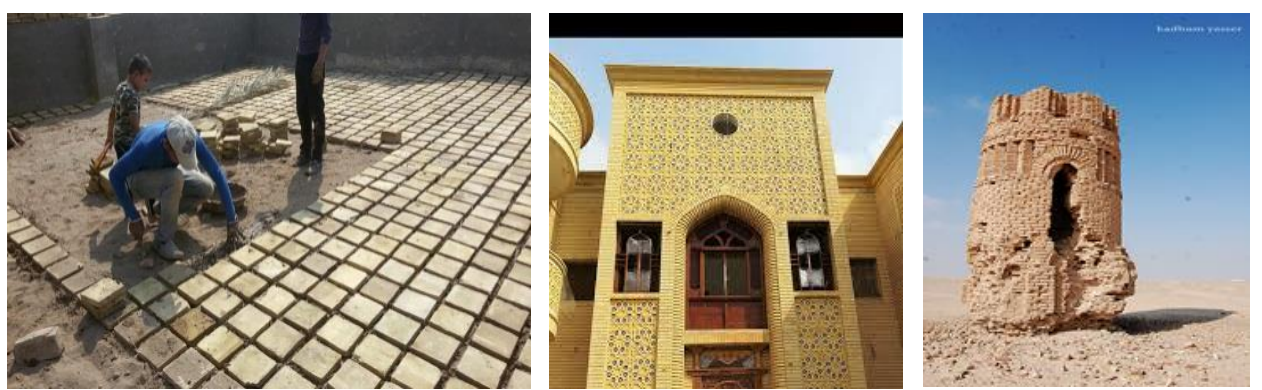

Fig. (3): Traditional clay bricks (Farshi) used for exposed tiling and other building purposes

dr.salahfarhan@gmail.com, adilhatem311@uoanbar.edu.iq, abdulelah_6@yahoo.com

${ }^{1}$ Corresponding author: College of Engineering, Al-Kitab University, A'alton Copry, Iraq 
In this research work, alternative materials have been developed to save energy and lower cost of construction. Lightweight tiles with lower thermal conductivity were manufactured and used, which helps to reduce loads and increase heat insulation of ceilings. The tiles used in this study were produced by the method of dry compression and high temperature burning, for the first time in Iraq. Two types of used clays, were withdrawn from quarries in the western region (Aamj and Husayniyat), which are recommended and characterized by (General Organization for Geological Survey and Investigation of Metal, Ministry of Industry, Iraq) that these materials are containing high percentage of silicates and very low percentages of harmful magnesium oxides. The presence of silicate in the clay helps, after burning at high temperatures, on the acquisition of tiles producing hardness and high compressive strength due the created ceramic shell surfaces.

The mixture of wheat straw with clay was used, in this research work, as a mortar to stabilize and fix the produced clay tiles on the concrete surface after coating with asphalt or water-proof sheets as shown in figure 4. By using this method of roofing it results a lightweight surface, high insulation of heat and noise, with minimal cost compared with the typical method as shown in Table 1 .

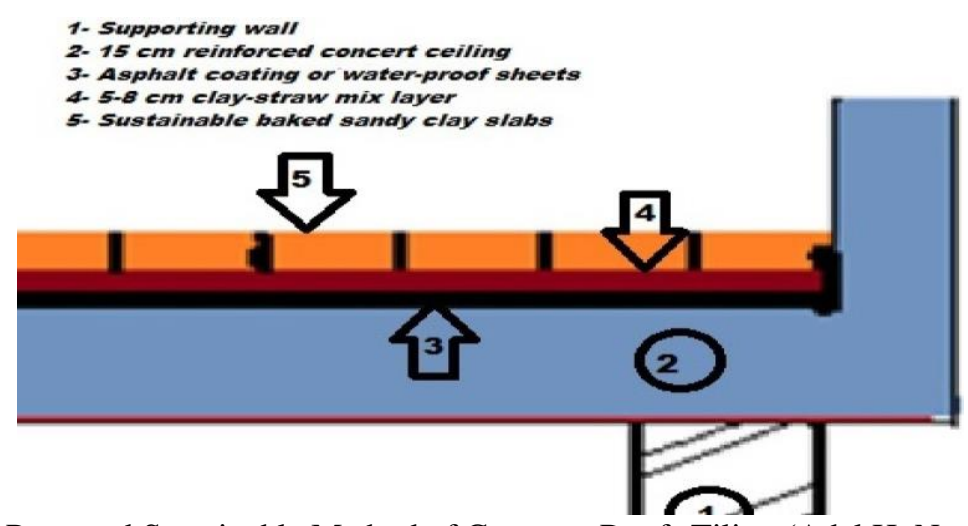

Fig. (4): Proposed Sustainable Method of Concrete Roofs Tiling (Adel H. Nawar, 2011)

\section{ENERGY SAVING CALCULATIONS}

A comparison between the traditional method and the sustainable method of surface coating shown in Table (1), which includes the details of the layers from which the packaging is used for both methods. The table also contains the coefficient of thermal conductivity of each material, which was taken from literature due to the lack of measuring instruments, where it was used to calculate the amount of heat that can be transmitted through the roof with different temperatures. In the summer period the temperature outside the room is assumed between 40-45 degrees Celsius while the room is cooled by air conditioners so that the temperature inside does not exceed 20-23 degrees Celsius and thus the heat will be transferred from the outside to the inside and on this basis the calculations were done. As for the winter, the process will be reverse. The temperature outside the room may be dropped down to $0^{\circ} \mathrm{C}$ and inside the room will be heated up to $23-30^{\circ} \mathrm{C}$. Calculations were performed by using the following equations and basic thermal conductivity principles (R. Taylor, Tools and Basic Information for Engineering and Design of Technical Applications, Engineering ToolBox and Neutrium)

Heat transfer through a surface like a wall or ceiling can be calculated as:

$q=U A d T$.

Where: $\mathrm{q}=$ heat transfer $(\mathrm{W}(\mathrm{J} / \mathrm{s}))$, $\left(\mathrm{W} /\left(\mathrm{m}^{2} \mathrm{~K}\right)\right)$

$\mathrm{U}=$ overall heat transfer coefficient

$$
\begin{aligned}
& A=\text { wall area }\left(\mathrm{m}^{2}\right) \\
& \mathrm{dT}=\left(\mathrm{t}_{1}-\mathrm{t}_{2}\right)=\text { temperature difference }
\end{aligned}
$$

over wall $\left({ }^{\circ} \mathrm{C}\right)$,

The overall heat transfer coefficient for a multi-layered wall or ceiling, Figure 5, with fluid flow on each side of the wall can be calculated as:

$1 / U A=\frac{1}{h_{c i} A_{i}}+\sum\left(\frac{s_{n}}{k_{n} A_{n}}\right)+\frac{1}{h_{c o} A_{o}} \ldots \ldots \ldots \ldots$

Where: $\mathrm{U}=$ the overall heat transfer coefficient $\left(\mathrm{W} /\left(\mathrm{m}^{2} \mathrm{~K}\right)\right)$,

$\mathrm{k}_{\mathrm{n}}=$ thermal conductivity of material in layer $\mathrm{n},(\mathrm{W} /(\mathrm{m} \mathrm{K}))$,

dr.salahfarhan@gmail.com, adilhatem311@uoanbar.edu.iq, abdulelah_6@yahoo.com $280{ }^{1}$ Corresponding author: College of Engineering, Al-Kitab University, A'alton Copry, Iraq 
$\mathrm{h}_{\mathrm{c} i, \mathrm{o}}=$ inside or outside wall individual fluid convection heat transfer coefficient $\left(\mathrm{W} /\left(\mathrm{m}^{2} \mathrm{~K}\right)\right)$, $\mathrm{s}_{\mathrm{n}}=$ thickness of layer $\mathrm{n},(\mathrm{m})$
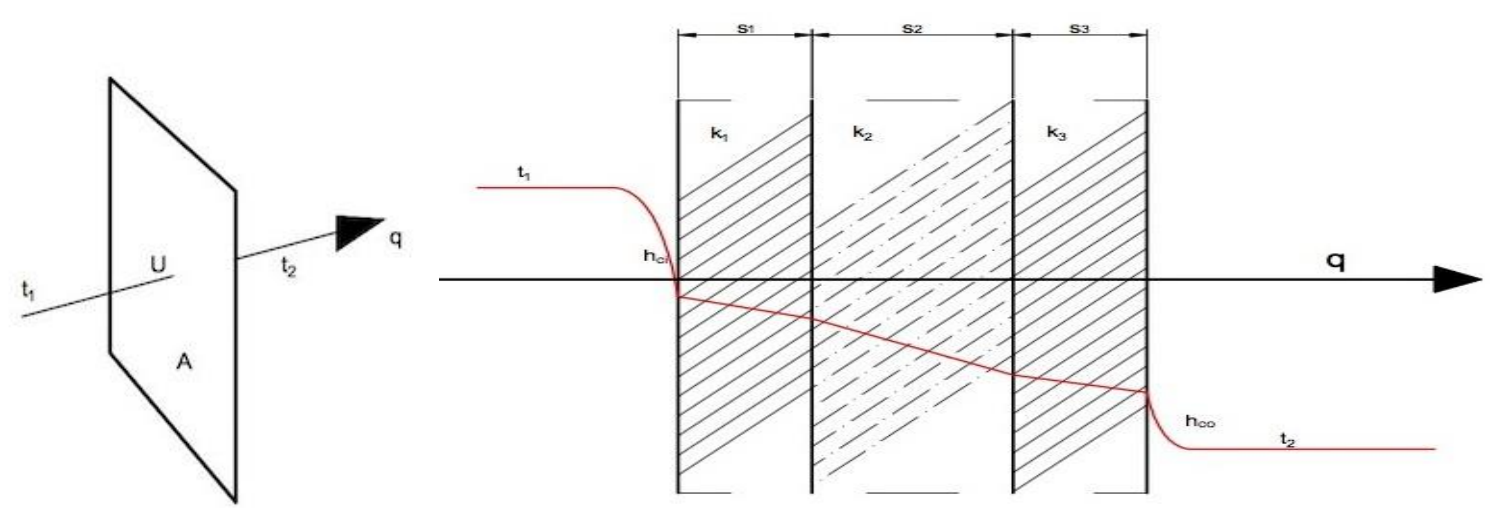

Fig. (5): Heat transfer through single or multi-layer wall or ceiling

A plane wall with equal area (assumed

$\left.1 \mathrm{~m}^{2}\right)$ in all layers - can be simplified to:

$$
1 / U=\frac{1}{h_{c i}}+\sum\left(\frac{s_{n}}{k_{n}}\right)+\frac{1}{h_{c o}}
$$

Conductivity is a property that may vary with temperature. Table (1) shows the approximate average coefficient of thermal conductivity of materials used in this study were taken from (Neutrium and Engineering ToolBox) for the simplicity and rough estimation.

The convection heat transfer coefficient (h) depends on type of fluid - if its air, gas or liquid, flow properties like velocity and other flow and temperature dependent properties. Convective heat transfer coefficient for air is $=10$ to 100 $\mathrm{W} / \mathrm{m}^{2} \mathrm{~K}$. Table (1) shows the calculated heat transfer rate $\mathrm{q}\left(\mathrm{kcal} /\left(\mathrm{h} \mathrm{m}^{2}{ }^{\circ} \mathrm{C}\right)\right)$ through each layer and the total $\mathrm{q}$ through the combinations for compared.

Table (1) and Figure (6) shows the vast differences between the traditional method and the sustainable method in terms of overall heat transfer reduction $(\mathrm{U})$, calculated heat transfer rate (q) and thermal conductivity (k) added to the decreased construction costs. This supports the need to continue and expand the use of sustainable construction materials and to conduct further research on the subject of this research.

Traditionally, price was the primary consideration when comparing alternative construction materials or materials intended for the same purpose. However, the building's total price represents only manufacturing and transportation costs, not social or environmental costs. The modern concept of choosing environmentally sustainable building materials is the way engineers and architects begin to integrate the principles of sustainable design into buildings. This means choosing materials to achieve lower social and environmental costs (Peter O. Akadiri, Ezekiel A. Chinyio, and Paul O. Olomolaiye,

2012)

Table (1): Comparison between Traditional and Sustainable Methods of Concrete Roofs Tilling

\begin{tabular}{|c|c|c|c|c|c|c|c|}
\hline $\begin{array}{c}\text { Method of } \\
\text { Encapsulation }\end{array}$ & $\begin{array}{l}\text { Layers Contents } \\
\text { of Encapsulation }\end{array}$ & $\begin{array}{c}\text { Density } \\
(\rho) \\
\left(\mathrm{kg} / \mathrm{m}^{3}\right)\end{array}$ & $\begin{array}{l}\text { Thermal } \\
\text { Conductivity } \\
\qquad(k) \\
\text { W/(m K) }\end{array}$ & $\begin{array}{c}\text { Over All } \\
\text { Heat } \\
\text { Transfer } \\
\text { Coefficient } \\
\quad(\mathrm{U}) \\
\left(\mathrm{W} /\left(\mathrm{m}^{2} \mathrm{~K}\right)\right.\end{array}$ & $\begin{array}{c}\text { Calculated } \\
\text { Heat } \\
\text { Transfer } \\
\text { Rate (q) } \\
\text { (W (J/s) }\end{array}$ & $\begin{array}{c}\text { Estimated } \\
\text { Weight } \\
\left(\mathbf{k g} / \mathbf{m}^{2}\right)\end{array}$ & $\begin{array}{l}\text { Estimated } \\
\text { Cost } \\
\left(\$ / \mathrm{m}^{2}\right)^{\star *}\end{array}$ \\
\hline \multirow{4}{*}{ Traditional } & $\begin{array}{l}\text { Asphalt coating } \\
\text { layer }(0.2-0.4 \mathrm{~cm})\end{array}$ & 1100 & 0.75 & \multirow{3}{*}{5.86} & \multirow{3}{*}{146.5} & 3.3 & 3 \\
\hline & $\begin{array}{l}\text { Stabilization River } \\
\text { Sand }(10-20 \mathrm{~cm})\end{array}$ & 1550 & 4 & & & 232.5 & 4 \\
\hline & $\begin{array}{l}\text { Concrete Slabs } \\
\left(5^{*} 80^{*} 80 \mathrm{~cm}\right)\end{array}$ & 2200 & 1.7 & & & 110 & 12 \\
\hline & & & Total & & & 345.8 & 19 \\
\hline
\end{tabular}

dr.salahfarhan@gmail.com, adilhatem311@uoanbar.edu.iq, abdulelah_6@yahoo.com

${ }^{1}$ Corresponding author: College of Engineering, Al-Kitab University, A'alton Copry, Iraq 
Journal of University of Duhok, Vol. 23, No.2 (Pure and Eng. Sciences), Pp 278-287, 2020 (Special Issue)

$3^{\text {rd }}$ international conference on recent innovations in engineering (ICRIE) Duhok, September 9-10-2020

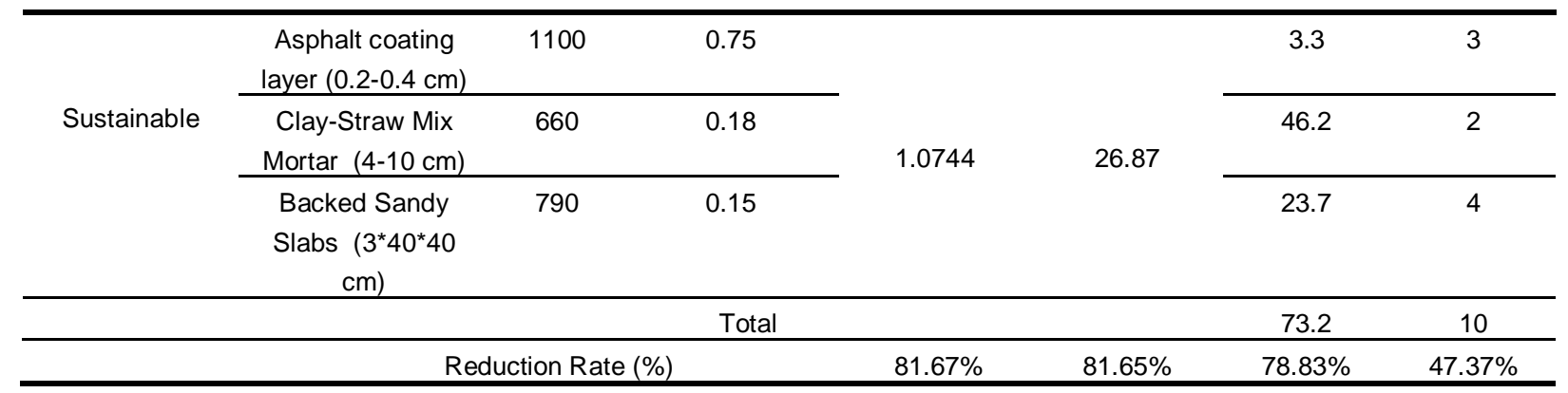

* Neutrium and Engineering ToolBox, Tools and Basic Information for Engineering and Design of Technical Applications, **Estimated according to local cost of Iraqi markets at April, 2020
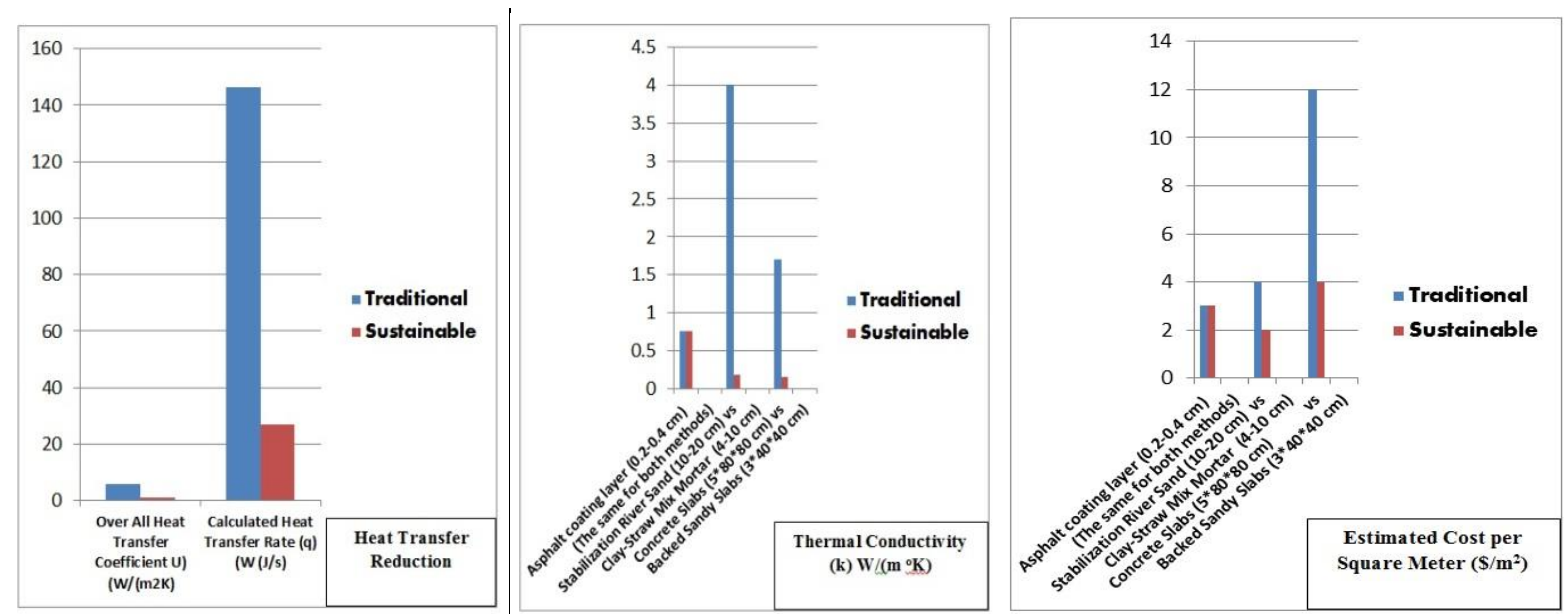

Figure 6. Comparison between Traditional and Sustainable Methods of Concrete Roofs Encapsulation

\section{EXPERIMENTAL WORK AND DISCUSSION}

\subsection{Manufactured Lightweight Slabs Characteristics}

Lightweight clay bricks have been in use for a long time and there is a lot of research and studies on this topic (Neslihan Dalkılıçn, June 2017 , and others). What is new in this research is that the clay is compressed, after being mixed with a small percentage of water (3-5\%), with a pressure ranging between $180-250$ bars or (18$25 \mathrm{MPa})$ inside a mold of $(40 \times 40 \times 3 \mathrm{~cm})$ dimensions. While the clay contains organic impurities (Table 2), when burning at high temperatures the organic materials contents helps to form gas bubbles inside the textures of the tiles causing lightweight structure. Silicon and aluminum oxides contents in the used samples might help, with high temperatures, to increase the hardness of the bubble walls which results in increased compressive and breakdown strength of the produced tiles. In other words, ceramic and aluminum texture could be the main factor of compressive and breakdown strength enhancement. The same method has been used to produce the Lightweight Expanded Clay Aggregates (LECA) which has a wide range uses in the sustainable construction industry (Xavier Kestemont Argex (XK), Nov. 2012, and Salah F. A. Sharif, 2018).

dr.salahfarhan@gmail.com, adilhatem311@uoanbar.edu.iq, abdulelah_6@yahoo.com $282{ }^{1}$ Corresponding author: College of Engineering, Al-Kitab University, A’alton Copry, Iraq 


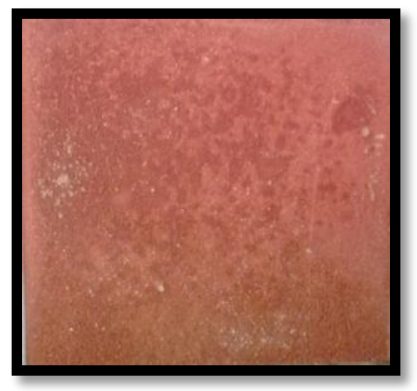

Before Burn

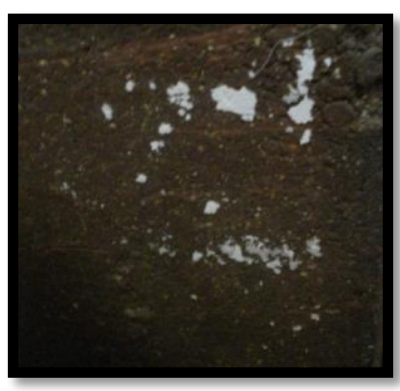

After Burn

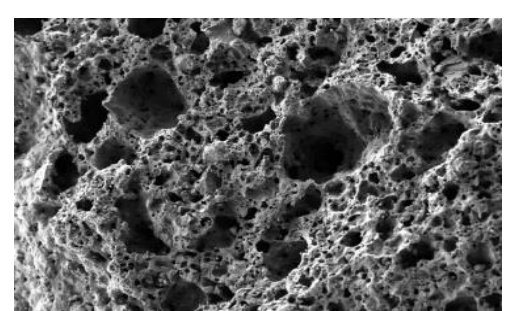

Specimen shows the texture

Fig. (7): Roofing Slabs before and after burning

\subsection{Slabs Manufacturing procedure}

Slabs were manufactured in the laboratories of Al-Anbar University, in a lab scale, and compressed in a local tiles factory and backed in the Lab furnaces of Ramadi Ceramic Industry. Production steps were as follows:

1. Two types of clay samples were selected, as in Table (2), which shows their chemical properties and the composition of each species. A'amj \& Al-Husayniat samples showed better chemical characteristics that they contain lower $\mathrm{MgO}, \mathrm{CaO}$, and $\mathrm{Fe}_{2} \mathrm{O}_{3}$ contents and higher silica percent. Tests were conducted in the laboratories of "General Organization for Geological Survey and Investigation of Metal / Ministry of Industry" that they have the authority and the capability to do such tests, which are not available in university laboratories.
2. The other added materials were:

- 2-3\% water for hydration.

- Silica sand (0-2.5mm grain size), for the purpose of reducing cracking during drying and mechanical compression moreover to strengthen the formed ceramic texture after burning.

3. Samples were left in the laboratory atmosphere for the initial natural drying, before burning.

4. The samples were burned in the lab vertical kiln with the indicated temperatures $(900,1000$, $\left.1100,1200,1230{ }^{\circ} \mathrm{C}\right)$. These temperatures are used to burn the ceramics, made of the same clay or other types, in Ramady Ceramic Industry.

5. Lightweight slabs were cooled and transported to the University labs for tests and investigations.

Table (2): Chemical properties of Clays from: Iraqi western desert (General Organization for Geological Survey and Investigation of Metal / Ministry of Industry, Report (839/1976) "Locations and geological data sources")

\begin{tabular}{ccccccccccc}
\hline & \multicolumn{7}{c}{ Chemical Properties (\%) } \\
\cline { 2 - 10 } $\begin{array}{c}\text { Type and } \\
\text { Location of } \\
\text { Clays }\end{array}$ & $\begin{array}{c}\text { Total } \\
\text { Soluble } \\
\text { Salts }\end{array}$ & $\begin{array}{c}\text { L.O.I. } \\
\text { (Organic } \\
\text { Impurities) }\end{array}$ & $\mathrm{Na}_{2} \mathrm{O}$ & $\mathrm{K}_{2} \mathrm{O}$ & $\mathrm{MgO}$ & $\mathrm{CaO}$ & $\mathrm{Fe}_{2} \mathrm{O}_{3}$ & $\mathrm{TiO}_{2}$ & $\mathrm{Al}_{2} \mathrm{O}_{3}$ & $\mathrm{SiO}_{2}$ \\
\hline $\begin{array}{c}\text { A'amj \& Al- } \\
\text { Husayniat }\end{array}$ & 1.49 & 10.12 & 0.89 & 0.73 & 0.14 & 0.81 & 4.13 & 0.91 & 30.24 & 51.20 \\
\hline $\begin{array}{c}\text { Al-Duar \& } \\
\text { Al-Abyed }\end{array}$ & 13.71 & 2.35 & 1.36 & 5.58 & 15.61 & 4.6 & & & & \\
\hline
\end{tabular}

\subsection{Lab Tests Results and Analysis}

Compressive strength, breakdown strength and water absorption of samples were investigated in the University laboratories according to (IS 1077, 1992 "Common Burnt Clay Building, Bricks - Specification", May 2008). Table 3 shows the compressive strength tests of four mixes samples using two types of raw materials withdrawn from Al-Anbar western desert. Results indicate that higher compressive strength was obtained with Red Clay A'amj \& Al-Husayniat samples with higher temperature $\left(1223^{\circ} \mathrm{C}\right)$. Higher percent's of $\mathrm{Al}_{2} \mathrm{O}_{3}$ and $\mathrm{SiO}_{2}$ in the raw materials with high temperature could be behind the increased compressive strength of samples 1 and 4 .

dr.salahfarhan@gmail.com, adilhatem311@uoanbar.edu.iq, abdulelah_6@yahoo.com 
Mechanism of increased compressive strength with increased burning temp, as shown in Figure 8, can be related to the creation of ceramic shells and outer surfaces as it is clear in the specimen section of Figure 7. Breakdown strength shown in Table (4) indicates that higher reading was obtained with sample (S.1) which consists of: red clay ( $80 \%)$ and glass sand $(20 \%)$ with high temp. This may confirm the role of increasing silicon content in the texture to increase both compressive and breakdown strength with increased burning temp. Results showed accepted compressive strength and break down strength of clay tiles compared with the standard clay tiles ((IS 1077, 1992).

Table (3): Compressive strength of samples after burning (M pa) (Mega Pascal)

\begin{tabular}{|c|c|c|c|c|}
\hline \multirow[b]{2}{*}{$\begin{array}{c}\text { Burning Temperature } \\
{ }^{\circ} \mathrm{C}\end{array}$} & \multicolumn{4}{|c|}{$\begin{array}{c}\text { Clay Type, Location* } \\
\text { \& Sample Dimensions }(\mathrm{mm})\end{array}$} \\
\hline & $\begin{array}{c}\text { S.1-Red Clay } \\
\text { A'amj \& Al- } \\
\text { Husayniat } \\
400 \times 400 \times 30\end{array}$ & $\begin{array}{c}\text { S.2-Red Clay } \\
\text { A'amj \& Al- } \\
\text { Husayniat } \\
400 \times 400 \times 30\end{array}$ & $\begin{array}{l}\text { S.3-White Clay } \\
\text { Al-Duar \& Al-Abyed } \\
400 \times 400 \times 25\end{array}$ & $\begin{array}{l}\text { S.4-Red Clay } \\
\text { A'amj \& Al- } \\
\text { Husayniat } \\
400 \times 400 \times 25\end{array}$ \\
\hline 900 & 0.68 & 0.62 & 0.40 & 0.4 \\
\hline 1000 & 0.91 & 0.84 & 0.89 & 0.81 \\
\hline 1100 & 1.77 & 1.60 & 2.68 & 2.08 \\
\hline 1180 & -- & -- & 4.10 & -- \\
\hline 1200 & 3.34 & 3.08 & -- & 3.26 \\
\hline 1230 & 3.51 & 3.30 & Invalid (Melt) & 3.70 \\
\hline
\end{tabular}

*The mixture design of Samples S.1, S.2, S.3, and S.4 are as follows:

- (S.1) consist of: red clay (80\%), glass sand (20\%),

- (S.2) consist of: red clay (90\%), glass sand (10\%),

- (S.3) consist of: white clay (100\%), glass sand (0\%),

- (S.4) consist of: red clay (100\%), glass sand (0\%)

- Water was added to all mixes in about $5 \%$ of the whole contents.

Table (4): Breakdown strength of samples after burning (M Pa)

\begin{tabular}{ccccc}
\hline \multirow{4}{*}{$\begin{array}{c}\text { Burning } \\
\text { Temperature } \\
{ }^{\circ} \mathbf{C}\end{array}$} & $\begin{array}{c}\text { S.1-Red Clay } \\
\text { A'amj \& Al- } \\
\text { Husayniat } \\
400 \times 400 \times 30\end{array}$ & $\begin{array}{c}\text { S.2-Red Clay } \\
\text { A'amj \& Al- } \\
\text { Husayniat }\end{array}$ & $\begin{array}{c}\text { S.3-Wight Clay } \\
\text { Al-Duar \& Al-Abyed }\end{array}$ & $\begin{array}{c}\text { S.4-Red Clay } \\
\text { A'amj \& Al- } \\
\text { Husayniat }\end{array}$ \\
\hline 900 & 0.40 & $400 \times 400 \times 30$ & $400 \times 400 \times 25$ & $400 \times 400 \times 25$ \\
\hline 1000 & 0.90 & 0.40 & 0.40 & 0.43 \\
\hline 1100 & 1.18 & 0.89 & 0.85 & 1.09 \\
\hline 1180 & -- & 1.07 & 1.09 & -- \\
\hline 1200 & 1.40 & -- & 1.38 & 1.22 \\
\hline 1230 & 1.43 & 1.26 & -- & 1.33 \\
\hline
\end{tabular}

Water absorption test for the produced clay burned tiles showed, as it is shown in Figure 8-C and Table 5, that water absorption (\%) were increasing with increased burning temp who is mostly related to the higher number of voids created in the tiles structure due the emitted biogases with higher burning temperature. Comparing with (ISS 1077, 1992) and (Alaa A.
Shakir, Ali Ahmed Mohammed, 2013) water consumption rates shown in Table 5 is comparatively is accepted.

It is found that, by random experimental tests on many samples, that water not pass through tiles, which could be due to the ceramic surfaces of

tiles.

dr.salahfarhan@gmail.com, adilhatem311@uoanbar.edu.iq, abdulelah_6@yahoo.com $284{ }^{1}$ Corresponding author: College of Engineering, Al-Kitab University, A'alton Copry, Iraq 
Table (5): Water absorption of samples after burning (\%)

\begin{tabular}{ccccc}
\hline \multirow{5}{*}{$\begin{array}{c}\text { Clay Type, Location, \& Sample Dimensions (mm) } \\
\text { Temperature } \\
{ }^{\circ} \mathbf{C}\end{array}$} & $\begin{array}{c}\text { S.1-Red Clay } \\
\text { A'amj \& Al- } \\
\text { Husayniat } \\
400 \times 400 \times 30\end{array}$ & $\begin{array}{c}\text { S.2-Red Clay } \\
\text { A'amj \& Al- } \\
\text { Husayniat } \\
400 \times 400 \times 30\end{array}$ & $\begin{array}{c}\text { S.3-Wight Clay } \\
\text { Al-Duar \& Al- } \\
\text { Abyed }\end{array}$ & $\begin{array}{c}\text { S.4-Red Clay } \\
\text { A'amj \& Al- } \\
\text { Husayniat }\end{array}$ \\
\hline 900 & 10.20 & $400 \times 400 \times 25$ & $400 \times 400 \times 25$ \\
\hline 1000 & 10.30 & 10.40 & 10.05 & 10.77 \\
\hline 1100 & 11.21 & 11.21 & 10.70 & 11.45 \\
\hline 1180 & -- & -- & 11.81 & 12.34 \\
\hline 1200 & 11.94 & 11.90 & 12.86 & -- \\
\hline 1230 & 12.20 & 12.10 & -- & 13.09 \\
\hline
\end{tabular}

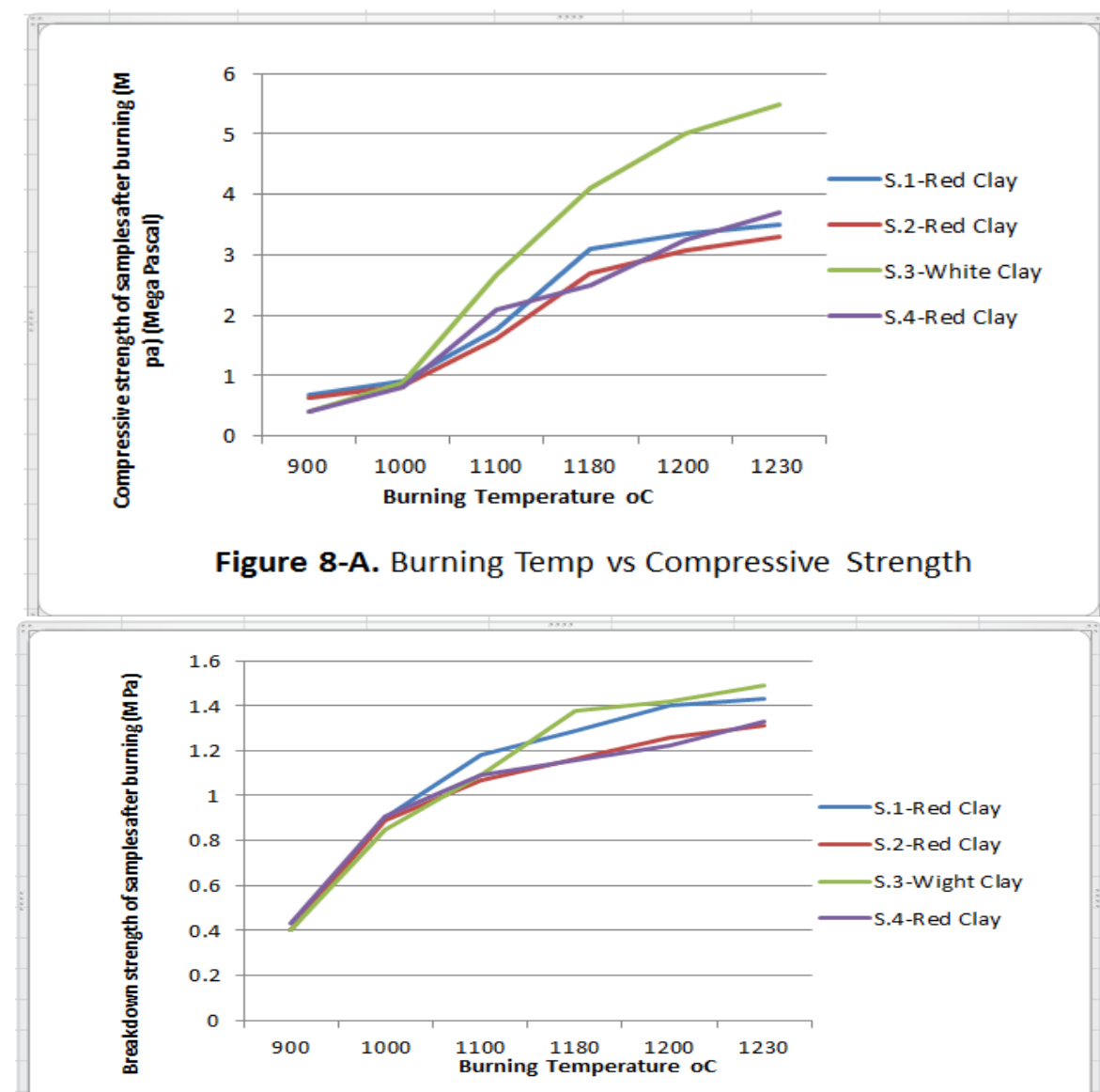

Figure 8-B. Burning Temp vs Breakdown Strength

dr.salahfarhan@gmail.com, adilhatem311@uoanbar.edu.iq, abdulelah_6@yahoo.com ${ }^{1}$ Corresponding author: College of Engineering, Al-Kitab University, A'alton Copry, Iraq 


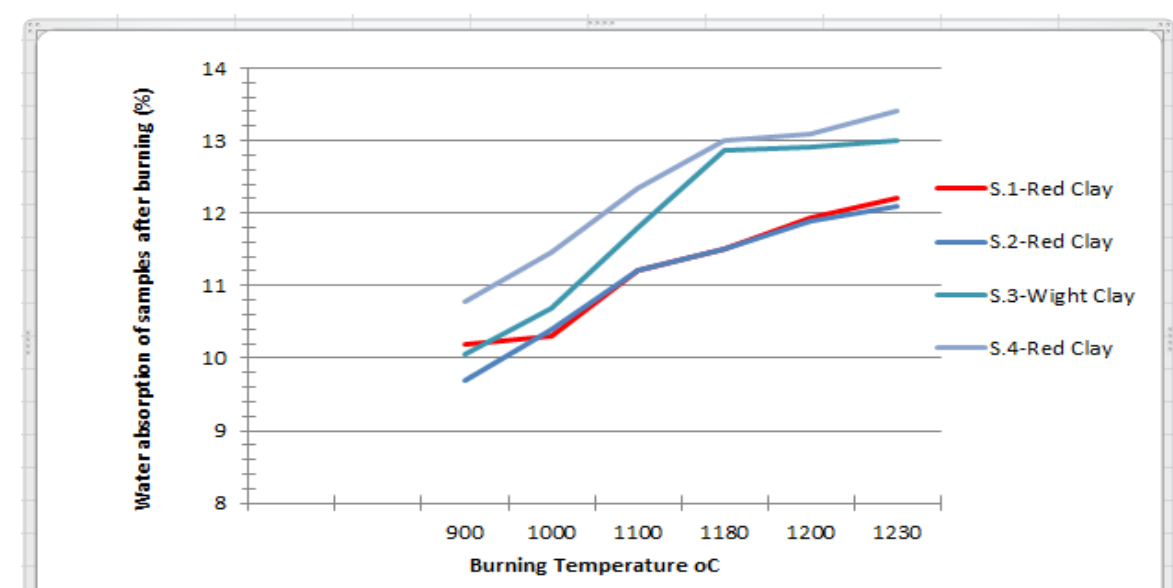

Figure 8-C. Brning Temp vs Water Absrption

Fig. (8): Effects of Burning Temp on the Compressive strength, Breakdown strength and Water absorption

\section{CONCLUSION}

Through this study and its results, it can be concluded that:

1- The traditional method of covering concrete surfaces in Iraq is not sustainable due to the use of construction materials that are not sustainable due to the high weight and the thermal conductivity factor of these materials, which results in depletion of resources, energy and high costs, and these calls for finding sustainable alternative methods.

2- The materials that were chosen in this research are all sustainable and available in nature, using part of them without any treatment (which is asphalt, clay, and straw) and the other section was used with simple treatment (which is the clay tiles after pressing and burning with simplified ovens).

3- The results showed that high differences and reduction rates in thermal insulation and weight, which result in reduced energy used in construction loads, material transfer and building air conditioning (cooling and heating), which helps reduce greenhouse gas emissions.

4- Chemical and physical analysis revealed that the best selected samples of raw materials were from A'amj \& Al-Husayniat quarries in the western desert.

5- Test results showed that higher silicon content in the selected raw materials, lower magnesium, and potassium and sodium compounds leads to better slabs specifications in high burning temperatures.
6- The results of the tests indicate the acceptability of the manufactured materials when compared to similar unsustainable materials and the required structural specifications.

7- There is no doubt that the research needs further study and examinations to improve the quality of the product that was invented in this research and to choose other sustainable construction materials as opposed to the traditional materials used to cover the concrete surfaces.

\section{REFERENCES}

A'aed Jassam, "Bricks Industry in Iraq", January 2014, See discussions, stats, and author profiles for this publication at: https://www.researchgate.net/publication/3253 34295 , .

Adel H. Nawar, "Use of local building materials in a sustainable urban residential environment" a $\mathrm{PhD}$ thesis presented to the Institute of Urban and Regional Planning for Postgraduate Studies/ University of Baghdad, 2011.

Alaa A. Shakir, Ali Ahmed Mohammed, "Manufacturing of Bricks in the Past, in the Present and in the Future: A state of the Art Review" International Journal of Advances in Applied Sciences (IJAAS), Vol. 2, No. 3, September 2013, pp. 145 156, ISSN: 22528814.

ATIF ALI, "THE EXPERIMENTAL STUDY FOR HEAT TRANSFERRED FROM BUILDING ROOFS AND ROOF FINISHING SYSTEM USAGE", The Iraqi Journal For Mechanical And Material Engineering, Vol.12, No.1, 2012,

dr.salahfarhan@gmail.com, adilhatem311@uoanbar.edu.iq, abdulelah_6@yahoo.com $286{ }^{1}$ Corresponding author: College of Engineering, Al-Kitab University, A'alton Copry, Iraq 
https://www.iasj.net/iasj?func=fulltext\&aId=6 $\underline{0020}$

Bohdan Stawiski, "Strength of Concrete in Slabs, Investigates along Direction of Concreting", Open Journal of Civil Engineering, 2012, 2, 22-26, doi:10.4236/ojce.2012.21004 Published Online March 2012 (http://www.SciRP.org/journal/ojce) DOI: 10.4018/978-1-5225-0302-6.ch001, In book: Smart Cities as a Solution for Reducing Urban Waste and Pollution.

General Organization for Geological Survey and Investigation of Metal / Ministry of Industry, Report (839/1976) "Locations and geological data sources"

Green Building and Sustainable Design, i4 Business, February 1, 2018, https://www.i4biz.com/bestpractice/green-building-sustainabledesign/\#: :text=Green \%20building $\% 20$ (also\% 20known\%20as, \%2C\%20maintenance $\% 2 \mathrm{C} \%$ 20renovation $\% 20$ and $\% 20$ demolition., http://www.iitk.ac.in/ce/test/IScodes/is.1077.1992.pdf

IS 1077 , 1992 "Common Burnt Clay Building, Bricks - Specification”, May 2008,

Neslihan Dalkılıçn, , Adnan Nabikoğlu, "Traditional manufacturing of clay brick used in the historical buildings of Diyarbakir (Turkey), Received 22 November 2016; accepted 23 June 2017, can be found in: Lightweight Clay Bricks Research Papers - Academia.edu, https://www.academia.edu/Documents/in/Ligh tweight_Clay Bricks

Neutrium, knowledge base of engineering topics, https://neutrium.net/heat-transfer/thermalconductivity-of-common-materials/

Peter O. Akadiri, Ezekiel A. Chinyio, and Paul O. Olomolaiye, "Design of A Sustainable
Building: A Conceptual Framework for Implementing Sustainability in the Building Sector”, Buildings 2012, 2, 126-152; doi:10.3390/buildings2020126, file:///C:/Users/SALAH/Downloads/buildings02-00126.pdf

R. Taylor, in Concise Encyclopedia of Advanced Ceramic Materials, 1991, “Thermal Conductivity" https://www.sciencedirect.com/topics/material s-science/thermal-conductivity

Rahul V. Ralegaonkar, Mangesh Madurwar, and Vishakha Sakhare, "Sustainable Construction Materials", June 2016

Salah F. A. Sharif, "Lightweight Expanded Clay Aggregates (LECA) Produced By Using Iraqi Western Desert Materials" 3rd Green \& Sustainable Chemistry Conference, 2018

Tools and Basic Information for Engineering and Design of Technical Applications, Engineering ToolBox, https://www.engineeringtoolbox.com/thermalconductivity-d_429.html

World Green Building Council, The benefits of green buildings, https://worldgbc.org/benefits-greenbuildings

Xavier Kestemont Argex (XK), SCI HQ, London "The manufacture and uses of expanded clay aggregate", 15 / Nov/ 2012.

Y. J. Kum, T. H. Wee, M. A. Mansur, "SHEAR STRENGTH OF LIGHTWEIGHT CONCRETE ONE-WAY SLABS", 32ndConference on OUR WORLD IN CONCRETE \& STRUCTURES: 28 - 29 August 2007, Singapore, http://cipremier.com/100032033 